\title{
Turopolje uzduž i poprijeko
}

\author{
Mladen Klemenčić \\ Leksikografski zavod Miroslav Krleža, Zagreb \\ mladen.klemencic@lzmk.hr
}

\begin{abstract}
SAŽETAK: Turopolje je jedna od tradicionalnih hrvatskih regija, među manjima po opsegu, ali prepoznatlijiva imena i obilježja. U razdoblju od 2018. do 2021. u Leksikografskom zavodu izrađeno je regionalno izdanje posvećeno Turopolju. Jedno od temeljnih pitanja za uredništvo Turopoljskoga leksikona bilo je odrediti područje koje regija obuhvaća. U članku se donosi pregled različitih definicija turopoljskoga područja u stručnoj literaturi kao i pregled promjena upravno-teritorijalne podjele koje su prethodile današnjem stanju, a koje su presudno na nj utjecale. Vodeći se načelom sveobuhvatnosti, uredništvo se odlučilo za širu definiciju područja po kojoj je Turopolje obuhvatilo današnje upravne jedinice grad Veliku Goricu i općine Kravarsko, Orle i Pokupsko, te dijelove (pojedina naselja) današnjega grada Zagreba i općine Lekenik.
\end{abstract}

Ključne riječi: horonim Turopolje; regionalizacija; Turopoljski leksikon

\section{Uvod}

Nakon što je Leksikografski zavod 2017. objavio Enciklopediju Hrvatskoga zagorja, objavio sam članak o tome kako smo u izradi izdanja u cijelosti posvećenoga regiji omeđili horonim Hrvatsko zagorje (Klemenčić, 2016-17). Kao član uredništva, od samoga početka sudjelovao sam u koncipiranju izdanja, a definicija područja koje treba obuhvatiti bilo je jedno od temeljnih koncepcijskih pitanja koje je tražilo precizan odgovor. S ciljem da iznađemo optimalnu definiciju pojma Hrvatsko zagorje, obavio sam uvid u postojeću literaturu, uzimajući pritom u obzir ponajprije one radove autori kojih su se i sami bavili tim pitanjem te se o njemu više ili manje precizno izjasnili. Enciklopedija Hrvatskoga zagorja bila je objavljena u zavodskome nizu Enciklopedije i leksikoni hrvatskih regija i gradova, a sljedeće izdanje u istome nizu posvećeno je jednoj od površinom najmanjih hrvatskih regija - Turopolju. Uredništvo, u kojem sam opet bio jedan od članova, ponovno se suočilo s istim pitanjem: koje područje treba obuhvatiti izdanjem - u ovom slučaju leksikonskim, ali to ne mijenja bit problema - koje u naslovu ima naziv regije. Posluživši se sličnim postupkom kao i u slučaju Hrvatskoga zagorja, prvo sam pregledao kako je Turopolje bilo definirano 
u stručnoj literaturi i drugim enciklopedijskim izdanjima, a potom sam, oslanjajući se i na dodatne kriterije pokušao iznaći optimalnu definiciju koju smo potom prihvatili kao radni okvir u izradi Turopoljskoga leksikona, a smatram da je prihvatljiva i u širem okviru kao zemljopisna definicija područja.

Turopolje je jedna od hrvatskih tradicionalnih regija, kakvih ima u svim dijelovima zemlje. Tradicionalne regije (primjerice Posavina, Gorski kotar ili Slavonija) međusobno se razlikuju po svom nastanku, neke su više povijesno uvjetovane, a druge ponajprije zemljopisno, kao što se razlikuju i po opsegu. Zajedničko im je da su u postojećoj upravnoj podjeli prisutne uglavnom na simboličan način, u nazivima pojedinih županija (Brodsko-posavska, Primorsko-goranska, Krapinsko-zagorska), dok u suvremenim geografskim regionalizacijama, temeljenima ponajprije na gravitacijskim područjima pojedinih gradova, za njih najčešće nema mjesta ili nisu cjelovito očuvane. Budući da su primarni kriteriji regionalizacije uglavnom bili druge naravi, one veće razbijene su na više jedinica, a one opsegom manje, a takvo je Turopolje, integrirane su u postojeće sustave upravne podjele i geografske regionalizacije. Uvodno treba još dodati i to da granice tradicionalnih hrvatskih regija nisu trajno zadane nego su vremenski promjenjive te su nerijetko ovisne o kontekstu razmatranja. Većini hrvatskih regija stoga nije moguće geometrijski precizno i uvijek na isti način odrediti granice. I Turopolje je takav zemljopisni pojam, granice kojega nisu svi autori opisivali jednako.

\section{Turopolje u geografskoj literaturi}

Kada je riječ o Turopolju u tradicionalnom smislu, prva asocijacija kod većine ljudi biti će da je riječ o nizinskom području u neposrednoj blizini Zagreba, koje se prostire južno od Save u smjeru Siska, gdje postupno prelazi u Pokuplje. Većina bi vjerojatno nizinskome dijelu pridružila i veći ili manji dio Vukomeričkih gorica, pobrđa u savsko-kupskome međuriječju. Kada je pak o Turopolju riječ u povijesnom kontekstu, najčešća asocijacija bit će specifičan oblik staleško-teritorijalne organizacije - Plemenita opčina Turopolje. Potonje potvrđuje definicija Turopolja u većini referentnih izdanja, primjerice u prvom izdanju Enciklopedije fugoslavije, u odnosnoj natuknici u osmome svesku, gdje se navodi: »U vezi s nastajanjem staleškog uređenja u XIII i XIV st. ti su podložnici...udruženi u 'plemenito bratstvo' (universitas nobilium Campi Zagrabiensis) koje je, pored toga što je bilo oslobođeno od plaćanja poreza, imalo pravo da bira svoga župana (comes terrestris)« (Blašković, 1971). Veći dio povijesnoga dijela turopoljske natuknice u spomenutoj enciklopediji u biti govori o povijesti Plemenite opčine Turopolje, poistovjećujući je na taj način potpuno sa zemljopisnom regijom.

U dvama najstarijim naslovima koje smo konzultirali, Turopolje je definirano na sličan način. V. Klaić smjestio ga je u Posavinu, »prostranu i dugu nizinu, koja se 
pružila uz rieku Savu od hrvatsko-kranjske medje sve do Zemuna«(Klaić, 1878: 186). Turopolje se spominje kao dio druge od pet kotlina koje se nižu duž Save, a koju je nazvao Zagrebačkom kotlinom (Klaić, 1878: 187-188). Dio te kotline južno od Zagreba naziva se Turopoljem, a u zagradi se navodi i latinski naziv Campus nobilium Turopolje. Na sličan način smješteno je i opisano i u drugome djelu istoga naziva (Hirc, 1905). I u tom izvoru dio je Posavine, podijeljene u šest većih kotlina, od koji se druga ponovno naziva Zagrebačkom, a »koja se raspada na više česti« (Hirc, 1905: 603). Njezin dio na lijevoj obali Save naziva se Zagrebačkim poljem, a na desnoj obali »od Zagreba do Lekenika, pruža se po luku-crljencu i lanu daleko znano Turo- ili Turovopolje, dugo preko 45, a široko preko $22 \mathrm{~km}$, koje se nekoć zvalo 'Zagrebačko polje'« (Hirc, 1905: 606).

Najcjelovitije je o Turopolju pisao M. Šenoa u radu objavljenom u ključnom višesveščanom djelu koje se obično pripisuje E. Laszowskom (Šenoa, 1910: 3-9). Definirajući položaj u okviru Hrvatske, Šenoa je Turopolje smjestio u Gornju Posavinu, širu regiju koja obuhvaća krajeve uz rijeku Savu, od Zagrebačke gore na sjeveru do ušća Une na jugu. Sama Sava to područje dijeli na dva dijela, veći na lijevoj obali rijeke i manji na njezinoj desnoj obali, a Turopolje se nalazi u manjem od tih dvaju dijelova kao njegova sjeverna sastavnica - »nizina na desnoj obali Save sve do Vukomeričkih gorica«. Na taj način opisano područje Šenoa je nazvao $»$ Turopoljem u širem smislu«.

Po Šenoi, Turopolje »u širem smislu«, dakle kao kompaktna zemljopisna regija, pretežito je nizinsko područje koje je na sjeveroistočnoj strani vrlo niskom vododjelnicom odijeljeno od Save, a na jugozapadnoj se strani lagano uzdiže u Vukomeričke gorice. $\mathrm{O}$ sjeverozapadnim i jugoistočnim međama Turopolja može se zaključiti iz usputnih Šenoinih primjedbi. Rijeka Lomnica, od koje u središnjem dijelu nastaje glavna turopoljska tekućica Odra, »ulazi ispod Male Mlake u Turopolje« iz čega se može zaključiti da se Turopolje u tom dijelu protezalo do zamišljene crte između naselja Čehi (Donji i Gornji) i Mala Mlaka. Prema jugoistoku pak Turopolje se protezalo »sve do ispod Peščenice«, što se može protumačiti da je obuhvatilo i Lekenik.

Isti autor iznosi donosi i drugu definiciju područja što ga je u to vrijeme obuhvaćala Plemenita opčina Turopolje, koja se sastojala od točno određenih naselja, koja se dijelom nalaze u Polju, a dijelom u Vrhovlju. Tako definirano područje Šenoa naziva »pravo Turopolje«, a »proteže se u spodobi polumjeseca koji je široko otvoren prema jugu«. Ono »započinje ...na Vrhovlju južno od mjesta Gustelnice i Dubranca, onda ide nešto prema istoku do Velike Gorice, a na jugoistok sve do ispod Peščenice« i očigledno je površinom manje od istoimenoga zemljopisnoga predjela. Plemenita opčina obuhvaćala je 13 sučija u nizinskom dijelu, odnosno u Polju, i osam sučija u brdskom dijelu, odnosno u Vrhovlju. Sučije u Polju bile su: Buševec, Velika Gorica, Mala Gorica, Hrašće, Kobilić, Kuče, Kurilovec, Donja Lomnica, Gornji i Donji Lu- 
kavec, Velika Mlaka, Mraclin, Pleso i Rakitovec, dok su sučije u Vrhovlju bile Bukovčak, Cerovski vrh, Cvetković Brdo, Dragonožec, Dubranec, Gustelnica, Prvonožina i Vukomerić. Osim navedenih naselja, u sučije su spadala i naselja Rakarje, Kušanec, Lazi, Gornja Lomnica, Lipnica, Markuševec, Havidić Selo, Petravci i Jarebić (Šenoa, 1910: 8). Uz popis naselja obuhvaćenih Plemenitom opčinom treba napomenuti da neka od spomenutih naselja danas nisu više samostalna naselja. Primjerice, današnje naselje Lukavec obuhvaća nekadašnji Donji Lukavec i Gornji Lukavec, dok je današnje naselje Velika Gorica aglomeracija nekadašnjih turopoljskih naselja, budući da, osim nekadašnje Velike Gorice, obuhvaća i Malu Goricu, Kurilovec, Pleso, Rakarje i Kušanec.

Kada se naselja navedena kao sastavnice Plemenite opčine označe na zemljovidu, ne dobije se prostorno homogeno i posve zaokruženo područje, jer između "plemenitaških « ima i drugih naselja koja nisu bila u sastavu Plemenite opčine, a čak kada bi se taj argument i ostavio po strani, na taj način definirano područje ne pokriva ni cjelokupno nizinsko područje južno od Zagreba, omeđeno Savom na sjeveru i istoku i Vukomeričkim goricama na zapadu, a kamoli cjelokupno nizinsko područje zajedno s onim dijelom Vukomeričkih gorica što se na njega nastavlja u smjeru juga.

Po svemu sudeći, Šenoa je već tada uočio problem koji u ovom radu nastojimo elaborirati, a to je razlika između pojma Turopolje definiranoga isključivo na temelju povijesne pripadnosti Plemenitoj opčini i Turopolja kao zemljopisnog pojma, horonima koji označava zaokruženu zemljopisnu regiju definiranu povijesnim, reljefnim, ali i drugim kriterijima. K tome treba dodati da navedene 22 sučije Plemenite opčine predstavljaju njezin unutrašnji ustroj iz kasnije etape postojanja i djelovanja, dok je u ranijim razvojnim etapama ta specifična staleška i teritorijalna organizacija uključivala i neka druga naselja. Jedno od takvih zasigurno je Odra gdje su se do XV. st. održavali i sastanci turopoljskih plemića. Odra je usto i jedna od najstarijih župa na tom području pa je ne samo nju nego i druga naselja koja su župi pripadala opravdano smatrati dijelom turopoljskoga područja. Nadalje, pojedina naselja, primjerice današnji Odranski Obrež, spominje i glavni povjesničar regije kao »selo...na zapadnoj medji turopoljskog kotara (Laszowski, 1910: 373). Drugim riječima, to znači da se Turopolje kao zemljopisna regija proteže i zapadnije od najzapadnijih sučija Plemenite opčine. $U$ istom izvoru, kao jedno od turopoljskih naselja naveden je i Lekenik »jer to je selo bilo nastanjeno kmetovima turopoljskih plemića« (Laszowski, 1910: 355).

Turopoljska zemljopisna regija prepoznata je, ali samo donekle omeđena, i u enciklopedijama i geografskim sintezama. Prilično opsežna natuknica objavljena je u Narodnoj enciklopediji srpsko-hrvatsko-slovenačkoj. Navedene su dvije definicije, u širem smislu to je »zapadni dio Posavine, od niže Zagreba do Siska između Save i Vukomjerićkih gorica«, a u užem smislu to je »pravo T., negda slobodna plemićska općina, zaprema 31 selo, koje u polju (19), koje u susjednom vrhovlju (12) Vukomjerić- 
kih gorica«. V. Blašković definirao je pak Turopolje u 8. svesku Enciklopedije fugoslavije (1971: 389) kao »izduženu nizinsku mikroregiju...između Save na istoku i sjeveru, Kupe na jugu i Vukomeričkih gorica na zapadu«. Blašković je, dakle, prihvatio Savu kao među na sjeveru i istoku, ali je na jugu uključio cjelokupno područje do Kupe, što znači praktički sve do Siska. U nacionalnoj geografskoj sintezi turopoljsko je područje obrađeno u okviru Središnje Hrvatske, jedne od pet hrvatskih makroregija, a u okviru te regije u podcjelini nazvanoj Zagrebačkom urbanom regijom (I. Jelen, 1974: 56). Ta podcjelina u današnjoj bi upravnoj podjeli odgovarala području Zagrebačke županije i Grada Zagreba. U daljoj raščlambi na manje prostorne cjeline, u Geografiji SR Hrvatske naziv Turopolje uopće se ne spominje, nego se govori isključivo o području tadašnje općine Velika Gorica.

U nacrtu regionalizacije Zagrebačke regije područje našega interesa označeno je kao jedinica nižega stupnja »velikogoričko-turopoljski periurbani prostor« i dio je jedinice višega reda koja prstenasto opasuje uže gradsko područje (Rogić, 1979-80: 156-157), međutim međe takve jedinice nisu preciznije navedene. Isti autor u drugom radu, u kojem iznosi nacrt uvjetno homogene regionalizacije, naš je prostor označio kao prostornu jedinicu najnižega, petoga stupnja, imenujući ga Turopoljsko-sisačkom Posavinom, a u sastavu jedinice višega stupnja imenovane Sjevernim Pokupljem (Rogić, 1983: 80).

Nešto detaljnije o međama Turopolja očitovala se B. Fürst-Bjeliš. Raspravljajući o prostornom obuhvatu Turopolja, kao problem uočila je međe, odnosno »kontakt prema Pokuplju i Posavini« (B. Fürst-Bjeliš: 1998: 85). Naime, na sjeveru i sjeveroistoku međa Turopolja jasno je određena prirodnom granicom, rijekom Savom. S obzirom na to da je Turopolje samim nazivom označeno kao nizinsko područje, donekle dvojbenom po njoj bi mogla biti pripadnost Vukomeričkih gorica, međutim na temelju kulturno-ekološke argumentacije zaključila je da »Vukomeričke gorice i nizinski prostor čine komplementarnu, logičnu proizvodno egzistencijalnu cjelinu«, a na temelju iste argumentacije smatrala je da se sastavnim dijelom Turopolja treba smatrati i Turopoljski lug. Dalje od toga, međutim, u svome radu nije išla pa je izostala precizna definicija na razini naselja, međutim njezina analiza uključila je i procjenu regionalnoga prostornoga obuhvata u svjetlu geografske nodalno-funkcionalne regionalizacije, zasnovane na stupnjevanju gravitacijskih područja urbanih središta. U tom svjetlu zaključila je da tradicionalno Turopolje »uključuje i neposredno povezuje različita područja, odnosno segmente Zagrebačke urbane regije...: grad u najužem smislu riječi (stvarni aglomeracijski prostor Zagreba), uži periurbani rub (velikogoričko-turopoljski) i njen vanjski periurbani rub (vukomeričko-pokupski)« (B. FürstBjeliš: 1998: 88-89).

$\mathrm{Na}$ tragu iznesene trodijelnosti jest i najnovija sustavna regionalizacija Hrvatske u okviru koje tradicionalno Turopolje nije prikazano kao cjelovita sastavnica, 
nego podijeljeno tako da je sjeverni dio s Velikom Goricom razvrstan u Zagorsko-prigorski prostor zagrebačke urbane regije, a južni dio u Sjeverno nepropusno Pokuplje (Magaš, 2013: 106). Štoviše, južni dio u Sjevernom nepropusnom Pokuplju na nižem je stupnju regionalizacije podijeljen u dvije podcjeline: Vukomeričko Pokuplje i Turopoljsko-sisačku Posavinu (Magaš, 2013: 113), pri čemu su obje spomenute sastavnice prikazane s područjem koje je šire od turopoljskoga područja koje je bilo predmetom našega interesa.

\section{Turopolje u upravno-teritorijalnim podjelama}

Budući da naselja odnosno sučije povijesne Plemenite opčine obuhvaćaju samo manji dio zemljopisne regije koja se nalazi između Zagreba i Siska, cjelovitiju podlogu za omeđenje područja potražili smo u upravno-teritorijalnom ustroju. U okviru upravno-teritorijalnoga ustroja, naime, Turopolje je najčešće i najdulje bilo istovjetno upravnoj jedinici (kotaru ili općini) sa sjedištem u Velikoj Gorici, no područje te jedinice mijenjalo se kad god se mijenjao i upravni ustroj, a te su promjene bile česte, pa je bilo potrebno obaviti uvid ne samo u današnju podjelu nego i u one koje su joj prethodile (Dubravica, 2018).

Za precizno i cjelovito određivanje područja Turopolja bitno je uzeti u obzir prostorni obuhvat upravne jedinice sa sjedištem u Velikoj Gorici, nedvojbenom regionalnom središtu područja između Zagreba i Siska u proteklih stoljeće i pol. Prema važećoj upravno-teritorijalnoj podjeli, koja je na snazi od sredine 1990-ih godina, turopoljsko se područje najvećim dijelom nalazi u sastavu grada Velike Gorice. Velikogoričko gradsko područje obuhvaća nizinski dio Turopolja i dio Vukomeričkih gorica te ima površinu od $552 \mathrm{~km}^{2}$ i jedna je od jedinica Zagrebačke županije. U sastavu su iste županije i tri manje općine, stanovništvo kojih u mnogočemu također gravitira Velikoj Gorici. Te su tri općine Kravarsko $\left(58,3 \mathrm{~km}^{2}\right)$, Orle $\left(57,6 \mathrm{~km}^{2}\right)$ i Pokupsko $\left(105,8 \mathrm{~km}^{2}\right)$. Općina Orle obuhvaća krajnji istočni rub širega turopoljskoga područja uz rijeku Savu odnosno Turopoljsku Posavinu, općina Kravarsko obuhvaća dio Vukomeričkih gorica, a općina Pokupsko južni dio Vukomeričkih gorica, u literaturi nazivan i Vukomeričkim pokupljem (Blašković, 1967). Područja svih triju općina u prošlosti povremeno su također bili sastavni dijelovi upravne jedinice sa sjedištem u Velikoj Gorici, a najdugotrajnije su bila u sastavu općine Velika Gorica u razdoblju 1962-90. Kada se tadašnja općina Velika Gorica usporedi s današnjom upravno-teritorijalnom podjelom, vidi se da su postojeće jedinice dobivene tako da je ona podijeljena na četiri površinom manje jedinice. Međutim, niti te četiri jedinice uzete zajedno, nisu dovoljne da se zaokruži zemljopisna regija, budući da je u dalinjoj prošlosti velikogorička upravna jedinica obuhvaćala i druga područja, poglavito u smjeru zapada, gdje je danas upravno područje Grada Zagreba odnosno juga, gdje je danas općina Lekenik u sastavu Sisačko-moslavačke županije. 
U drugoj polovici XIX. st., kada je uveden upravno-teritorijalni ustroj u modernom smislu, a osobito po stanju nakon 1886., turopoljsko je područje odgovaralo opsegu velikogoričkoga kotara u Zagrebačkoj županiji. U sastavu kotara Velika Gorica nakon 1886. bile su tri općine: Odra na zapadu kotara, Orle na istoku kotara i Velika Gorica koja je zauzimala najveći, središnji dio kotara. Općina Velika Gorica 1893. podijeljena je na četiri manje općine: Dubranec, Vukovina, Kravarsko i Velika Gorica. Za naše razmatranje bitna je, ponajprije, daljnja sudbina općine Odra koja je zauzimala područje najbliže Zagrebu. Početkom XX. st. započeo je proces širenja zagrebačkoga područja na staro turopoljsko (velikogoričko) područje. Najprije je 1910., još uvijek unutar velikogoričkoga kotara, iz općine Odra u zasebnu općinu izdvojena općina Sveta Klara, koja je 1912. priključena zagrebačkom kotaru, a potom je 1913. iz općine Odra izdvojena i općina Brezovica te također priključena zagrebačkom kotaru. Godine 1952. iz općine Odra i velikogoričkoga kotara izdvojena su nase-

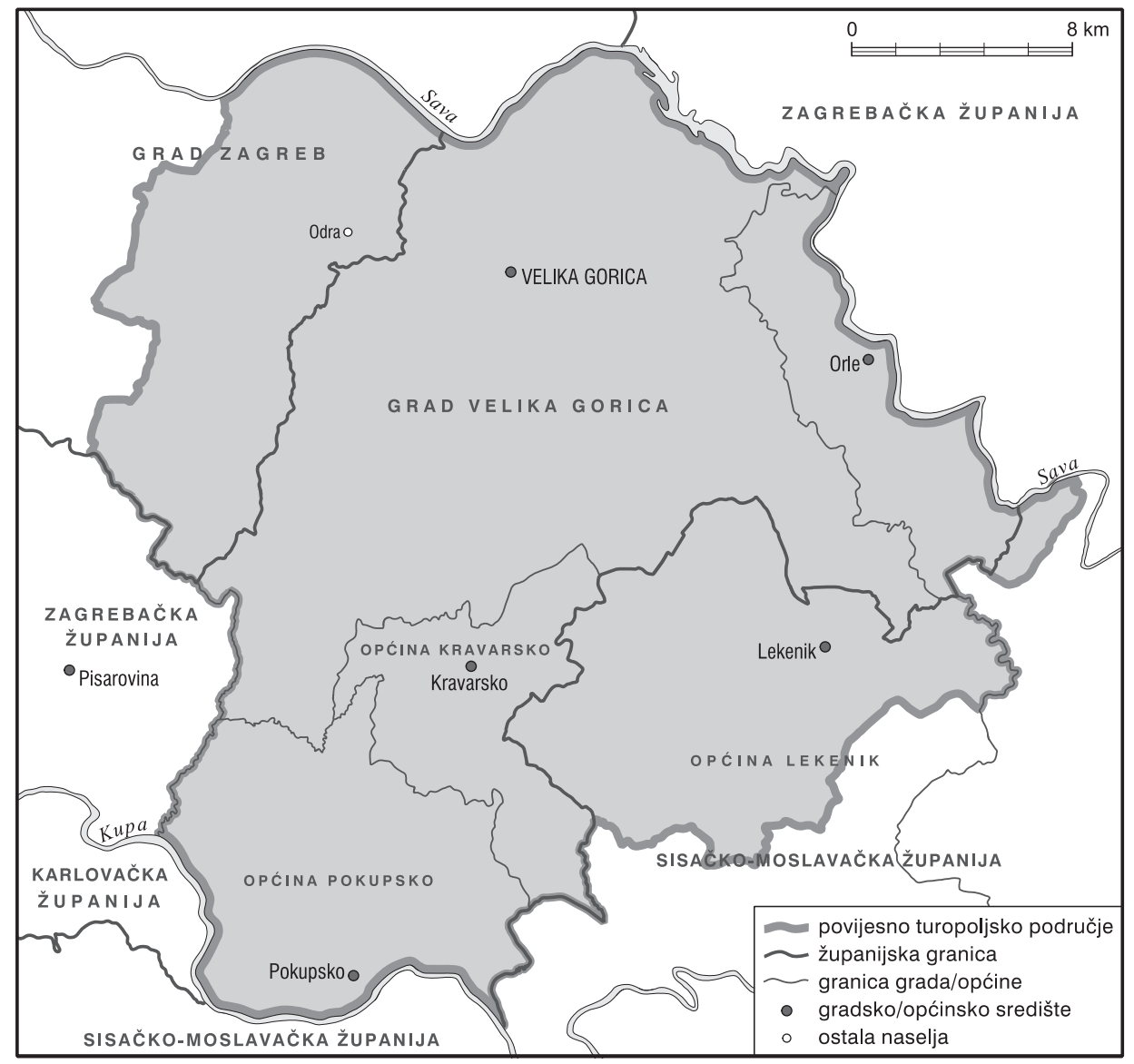

Slika 1. Karta Turopolja s postojećim upravnim jedinicama 
lja Odranski Obrež i Strmec te priključena zagrebačkom kotaru. Naposljetku je 1955. preostalo, tada već smanjeno područje općine Odra, zajedno s pojedinim naseljima općine Dubranec, izdvojeno iz velikogoričkoga kotara 1955. te priključeno novoformiranoj općini Remetinec (preteča općine Novi Zagreb). Tom promjenom ustroja prekida se upravno-teritorijalna povezanost odranskoga područja s ostatkom Turopolja, odnosno s velikogoričkom upravnom jedinicom. Od 1963. najveći dio turopoljskoga područja bio je u sastavu općine Velika Gorica, koja je 1974. postala jednom od gradskih općina Zagreba. U razdoblju 1990-95. cijela je dotadašnja općina Velika Gorica bila područni ured u sastavu jedinstvene općine Grad Zagreb, no 1995. obnovljena je velikogorička upravna jedinica u statusu grada, a formirane su i današnje općine Kravarsko, Orle i Pokupsko. Kao rezultat spomenutih promjena, današnje velikogoričko gradsko područje koje obuhvaća najveći dio povijesnoga Turopolja upravna je jedinica u Zagrebačkoj županiji, a zapadni dio povijesnoga Turopolja nalazi se unutar zagrebačke upravne jedinice (Grad Zagreb).

$\mathrm{Na}$ temelju iznesenih promjena bilo je jasno da u Turopolje, barem kada je o leksikonskoj sintezi riječ, svakako treba uključiti i nekadašnju općinu Odra, no s obzirom na širenje područja urbaniziranoga područja grada Zagreba, javila se dvojba treba li ju uključiti u punom povijesnom opsegu ili samo djelomično. Budući da se Zagreb u drugoj polovici XX. st. proširio na južnu obalu Save pa su nekadašnja naselja sjevernoga dijela povijesne odranske općine danas sastavni dijelovi gradskih četvrti grada Zagreba, procijenili smo da tu činjenicu valja uvažiti. Stoga smo u Turopolje uključili samo naselja koja i danas postoje kao statistički samostalna naselja, ukupno 15 naselja iz sastava Grada Zagreba, dok nekadašnja odranska naselja, primjerice Svetu Klaru, Jakuševec ili Brezovicu, danas mjesne odbore u sastavu zagrebačkih gradskih četvrti, nismo uzeli u obzir, odnosno naznačili smo ih uvjetno, kao periferne ili povijesne sastavnice Turopolja. U okviru fizičkoga i upravnoga proširenja Zagreba, nastale su i fizičke prepreke preko kojih je nema smisla ići bez obzira na povijesne činjenice. Kao moguće, fizički itekako vidljive granice na terenu, u tom se kontekstu ističu dvije prometnice: najprije je 1978. izgrađen ranžirni kolodvor, a potom 1981. i zagrebačka cestovna obilaznica koja vjerojatno nije krajnja južna crta širenja Zagreba, ali je nakon njezine izgradnje postalo nezamislivo da bi se područje sjeverno od nje i dalje smatralo dijelom Turopolja.

Južnu među Turopolja »pomaknuli« smo južnije od današnje granice Zagrebačke i Sisačko-moslavačke županije tako da smo u Turopolje u zemljopisnom pogledu uključili i općinu Lekenik, ali ne cijelom površinom nego njezin sjeverni dio s ukupno osam naselja, uključujući dakako i sam Lekenik. Kao podlogu uzeli smo činjenicu da je u jednoj od najranijih varijanti teritorijalnoga ustroja, od 1871. do 1875. u sastavu kotara Velika Gorica bila i općina Lekenik (Dubravica, 2018: 30). Površina tadašnje općine Lekenik bila je manja od današnje i odgovarala je području župe Pešćenica, stare turopoljske crkvene jedinice. 
Objašnjenje zahtijeva i uključivanje općine Pokupsko. Pokupski dio Vukomeričkih gorica, područje južno od vododijelnice između Odre i Kupe, reljefno nagnut prema potonjoj, nije neupitan dio zemljopisnoga Turopolja, iako s Turopoljem ima zajedničkih obilježja. Povijesno je to područje najčešće bilo zasebna općina, koja sve do 1952. nije bila u sastavu velikogoričkoga kotara, međutim, nakon što je 1962. ušlo u sastav općine Velika Gorica, ono i upravno postaje upućeno na Turopolje.

Crkveno-teritorijalna podjela također je poslužila kao dobar argument u smjeru predloženih rješenja. Kao ključna jedinica u tom kontekstu izdvaja se Odranski dekanat (od 2001. preimenovan u Odransko-velikogorički dekanat) i to u opsegu što ga je ta crkvena jedinica imala do 2009. U skladu s uobičajenim načinom imenovanja, dekanati, crkvene jedinice koje obuhvaćaju desetak župa, imenuju se prema nazivima starih gradova, gora ili rijeka koje protječu dotičnim područjem pa je i taj dekanat imenovan prema rijeci Odri. Njegov opseg u razdoblju do 2009. zanimljiv je zato što je obuhvaćao najveći dio turopoljskoga područja. Uza sve župe koje se neupitno mogu smatrati turopoljskima (primjerice, Dubranec, Donja Lomnica, Odra, Kravarsko, tri velikogoričke župe itd.), Odranski je dekanat obuhvaćao i župe na rubnom turopoljskom području. Na zapadu i na sjeveru to su bile župe Jakuševec i Sveta Klara, a na jugu župa Pešćenica (K. Matković Mikulčić, 1998). Izvan Odranskoga dekanata bila je jedino župa Pokupsko, tada u sastavu Pokupskoga dekanata (nazvanoga po rijeci Kupi). Nakon što je 2009. iz Zagrebačke nadbiskupije izdvojena Sisačka biskupija, došlo je i do promjena na nižim razinama crkvene podjele pa je nekadašnjem Odranskom dekanatu smanjen opseg, čime je izgubio sveturopoljski atribut. Neke turopoljske župe (Pešćenica, Veleševec) pripale su novoj Sisačkoj biskupiji, dok su župe Sveta Klara i Jakuševec pripale Novozagrebačkom dekanatu.

\section{Zaključak}

Područje Turopolja, pretežito nizinske regije na desnoj obali Save južno od Zagreba, ima samo djelomično neupitne međe prema susjednim područjima. Rijeka Sava neupitna je i jasna sjeverna i istočna međe regije, dok su zapadna i južna međa slabije izražene. Na zapadu, a djelomice i na sjeveru, na turopoljsko se područje nadovezuje prigradsko i gradsko (novozagrebačko) područje Zagreba. Uslijed upravnoga i fizičkoga širenja Zagreba tijekom XX. st., tradicionalno turopoljsko područje u tom je dijelu znatno smanjeno $u$ odnosu na povijesni opseg. Na jugu se na turopoljsku nizinu, bez izrazitije međe, nadovezuje donje Pokuplje, odnosno prigradsko područje grada Siska, pa je i u tom dijelu teže odrediti među između dvaju područja. Također na jugu, ali u brdskom području Vukomeričkih gorica, donekle je upitna uključenost krajnjega južnoga dijela najbližega rijeci Kupi, koji je u upravnom i crkvenom pogledu bio zasebna jedinica (općina i župa Pokupsko). U radu na Turopoljskom leksikonu i to je područje obrađeno kao sastavni dio Turopolja, uvažavajući donekle njegovu 
posebnost, ali pozivajući se ponajprije na činjenicu da je u razdoblju 1962-90. bilo sastavni dio općine Velika Gorica. Na taj način dobivena je zaokružena prostorna cjelina koja obuhvaća nešto manje od 1000 četvornih kilometara površine. S obzirom na važeću upravnu podjelu, na tom području četiri su upravne jedinice: grad Velika Gorica, kao najveća i po mnogo čemu središnja sastavnica, te općine Kravarsko, Orle i Pokupsko. Navedene upravne jedinice obuhvaćene su cjelovito, no osim njih, a zbog povijesnih razloga, tradicionalno turopoljsko područje poželjno je proširiti i na dio naselja koja su danas u sastavu Grada Zagreba (nekadašnja odranska općina) odnosno u sastavu općine Lekenik (nekadašnja župa Pešćenica). Na tako omeđenom području turopoljski regionalni identitet nije posvuda jednako izražen, razlikuju se jezgra i periferija, odnosno rubni ili prijelazni dijelovi prema susjednim područjima. Jezgrom turopoljske regije u upravnom smislu može se smatrati današnje područje u sastavu velikogoričke upravne jedinice, a u povijesnom smislu, presudnom kada je riječ o kulturno-geografskom identitetu, to je područje koje su obuhvaćale sučije Plemenite opčine Turopolje.

\section{LITERATURA}

Blašković, Vladimir (1967). Temeline geografske oznake Vukomeričkog pokuplja, Geografski glasnik, XXIX, str. 15-41.

Blašković, Vladimir (1971). Turopolje. Enciklopedija fugoslavije, sv. 8. Zagreb.

Dubravica, Branko, (2018). Teritorijalni ustroj Velike Gorice od kotara i općine do grada (1871.-1995.), Velika Gorica.

Enciklopedija Hrvatskoga zagorja, Zagreb 2017.

Fürst-Bjeliš, Borna (1998). Turopolje - položaj tradicionalne regije u sustavu geografske regionalizacije, Acta Geografica Croatica, 33, 1, str. 83-89.

Fürst-Bjeliš, Borna (2005). Turopolje, Meridijani, 94, str. 48-57.

Hirc, Dragutin (1905). Prirodni zemljopis Hrvatske, Zagreb.

Jelen, Ivan (1974). Zagrebačka urbana regija, Geografija SR Hrvatske, knj. 2, str. 7-60.

Klaić, Vjekoslav (1878). Prirodni zemljopis Hrvatske, Zagreb.

Klemenčić, Mladen (2016-17). Što je Hrvatsko zagorje?, Studia lexicographica, 19/20, str. 19-34.

Laszowski, Emilij (1910). Povijest Plem. općine Turopolja nekoć Zagrebačko polje zvane, sv. I., Velika Gorica.

Magaš, Damir (2013). Geografija Hrvatske, Zadar.

Matković Mikulčić, Katja (1998). Crkve i kapele Odranskog i Pokupskog dekanata, Velika Gorica.

Rogić, Veljko (1979-80). Zagrebačka regija - prilog poznavanju problematike geografske diferencijacije urbanih regija, Geografski glasnik, XLI-XLII, str. 149-160.

Rogić, Veljko (1983). Nacrt uvjetno homogene regionalizacije SR Hrvatske, Geografski glasnik, 45, str. $75-89$.

Stanojević, Stanoje (1929). Narodna enciklopedija srpsko-hrvatsko-slovenačka, knj. IV (S-Ž), Zagreb.

Šenoa, Milan (1910). Zemljopis i narodopis, u. E. Laszowski, Povijest Plem. općine Turopolja nekoć Zagrebačko polje zvane, sv. I., str. 1-31. 


\title{
TUROPOLJE: ALL ALONG AND ACROSS
}

\author{
Mladen Klemenčić \\ The Miroslav Krleža Institute of Lexicography, Zagreb \\ mladen.klemencic@lzmk.hr
}

\begin{abstract}
Among traditional Croatian regions Turopolje is one of the smallest, but also one with a widely recognizable name and distinctive characteristics. Between 2018 and 2021, The Miroslav Krleža Institute of Lexicography compiled the edition devoted exclusively to the Turopolje region. One of the basic conceptional issues for its editors was to determine the area of the region and consequently define the area which is to be embraced by the research. This article reviews different territorial definitions of Turopolje as well as changes in administrative-territorial divisions during last century and a half, which preceeded actual situation. Taking into account that encyclopedias generally tend to apply a holistic approach, the editors decided to include present-day administrative units the township of Velika Gorica, communes of Kravarsko, Orle and Pokupsko, as well as parts (particular settlements) of the township of Zagreb and the commune of Lekenik.
\end{abstract}

Keywords: horonym Turopolje; regionalization; The Turopolje Lexicon 